\title{
MENINGKATKAN BERPIKIR KREATIF DAN HASIL BELAJAR MENGGUNAKAN MODEL PjBL BERBASIS STEAM PADA MATERI LARUTAN ELEKTROLIT DAN NONELEKTROLIT
}

\section{Improving Creative Thinking And Learning Results Using Steam-Based Pjbl Models In The Study Of Electrolyte And Non-Electrolyte}

Muhammad Kholilul Rahman*, Bambang Suharto, Rilia Iriani

Program Studi Pendidikan Kimia FKIP Universitas Lambung Mangkurat, Jl. Brigjen H. Hasan Basry Banjarmasin 70123 Kalimantan Selatan Indonesia *email: rhmankholil@gmail.com

\begin{abstract}
Abstrak. Penelitian tentang meningkatkan berpikir kreatif dan hasil belajar peserta didik menggunakan model PjBL berbasis STEAM materi elektrolit dan nonelektrolit di SMAN 7 Banjarmasin bertujuan untuk mengetahui 1) Tindakan yang tepat dalam upaya menangani masalah kelas 2) meningkatkan berpikir kreatif serta hasil belajar. Jenis Penelitian yang diterapkan adalah PTK Model John Elliot dengan tahap rencana, tindakan, pengamatan, dan refleksi, dilakukan di SMAN 7 Banjarmasin di kelas X MIPA 5 dengan objek 38 peserta didik. Aspek yang diteliti yaitu guru dan peserta didik. Penelitian ini mendapatkan hasil bahwa, dengan menggunakan model PjBL berbasis STEAM ditemukan tindakan yang tepat untuk peserta didik yaitu 1) bertukar pikiran dengan kelompok, 2) memberikan opsi/pilihan jawaban,3) memberikan arahan dalam pembuatan proyek mading 3 dimensi berbasis STEAM, 4) membimbing dalam mengajukan pertanyaan, sehingga keberhasilan tindakan disertai dengan peningkatan berpikir kreatif dan hasil belajar. Penggunaan Model $P j B L$ berbasis STEAM, dapat meningkatkan berpikir kreatif serta hasil belajar. Pada siklus I yaitu 9,36 dikategorikan cukup kreatif dan siklus II yaitu 11,55 dikategorikan kreatif. sedangkan hasil belajar pada siklus I yaitu 63,15 dengan kategori rendah dan pada siklus II sebesar 92,10 dengan kategori Sangat tinggi.
\end{abstract}

Kata kunci: $P j B L$ berbasis STEAM, Berpikir kreatif, tindakan.

Abstract. Research on improving creative thinking and learning outcomes of students using the STEAM-based PjBL model on electrolyte and nonelectrolyte material at SMAN 7 Banjarmasin aims to find out 1) The right action in an effort to deal with class problems using the STEAM-based PjBL model to improve creative thinking and learning outcomes of participants educator 2) The use of STEAM-based PjBL models can improve creative thinking and 3) Improve student learning outcomes. This research applies John Elliot's Model Classroom Action Research which is started from the stages of planning, action, observation, and reflection, conducted at SMAN 7 Banjarmasin in class $\mathrm{X}$ MIPA 5, with 38 students as an object. The studied aspects included teacher actions, creative thinking, and learning outcomes of students. The results of this study indicated that using the STEAM-based PjBL model is the right action, such as ask the students to exchange ideas with other group, give some options/answers, provide direction in making project mading 3 STEAM-based dimensions and guide students to ask questions to other groups, give rewards to students who want to ask so that the success of the action is accompanied by an increase in creative thinking and learning outcomes. The use of STEAM-based PjBL Model can enhance students' creative thinking. In the first cycle 9.36 with the category quite creative and in the second cycle 11.55 with the creative category. The use of the STEAM-based PjBL Model can improve student learning outcomes in the first cycle of 63.15 in the low category and in the second cycle 92.10 with the very high category.

Copyright $\odot$ JCAE-Jurnal Tugas Akhir Mahasiswa, e-ISSN 2613-9782

Program Studi Pendidikan Kimia FKIP Universitas Lambung Mangkurat 
Keywords: PjBL based on STEAM, creative thinking, action

\section{PENDAHULUAN}

Pendidikan kimia adalah penggabungan prinsip pendidikan dan kimia dalam memahami konsep pembelajaran dengan tujuan memajukan kompetensi peserta didik agar dapat bersaing didunia kerja. Pembelajaran yang baik dapat membangun karakter peserta didik secara akademik, sosial, emosional, dan spiritual (Saptorini, 2014). Kimia dianggap sebagai mata pelajaran yang sulit karena kebanyakan materi pembelajaran kimia selalu berdasarkan fakta, konsep dan prosedural salah satunya materi elektrolit dan nonelektrolit.

Studi pendahuluan untuk mengetahui kemampuan berpikir kreatif dan hasil belajar peserta didik kelas X Mipa 5 SMAN 7 Banjarmasin diperoleh data yaitu. 1) menganalisis soal ujian akhir semester tahun ajaran 2017/2018, diperoleh informasi sebagian besar masih rendah dalam hal berpikir kreatif, melihat hasil analisis soal yang diberikan guru pada saat ulangan akhir semester, lebih banyak tingkatan soal C1-C3 saja, yang harusnya untuk membuat berpikir lebih berkembang berada pada tingkatan C4-C6. 2) Melakukan tes berpikir kreatif di kelas X MIPA 5 SMAN 7 Banjarmasin tahun ajaran 2018/2019, dari data ini menunjukan hanya 39,47\% yang tergolong cukup kreatif atau 15 orang dari 39 peserta didik, sedangkan 60,53\% atau 24 peserta didik yang lainnya tergolong kurang kreatif. 3) menganalisis hasil belajar di tahun ajaran 2017/2018 sebanyak 34 Peserta didik. Pada materi larutan elektrolit dan nonelektrolit, hampir semua peserta didik kurang memahami pelajaran yang berakibat pada hasil belajar kurang baik, terlihat cuma 5 Peserta didik yang lulus dari (KBM) dengan persentase yang tidak lulus $88,3 \%$.

Berpikir kreatif dan hasil belajar kurang maksimal dikarenakan beberapa faktor, diantaranya faktor internal seperti kesiapan dan minat peserta didik masih kurang, sedangkan faktor lain yang mempengaruhinya adalah faktor eksternal seperti pembelajaran di dalam kelas kurang bervariasi, membuat kejenuhan dalam proses menerima pengetahuan. Solusi yang dilakukan yaitu menghadirkan pembelajaran menggunakan model K 13 yang inovatif dan menunjang kreatifitas peserta didik salah satunya adalah model $P j B L$ (project based learning) yang dapat mengatasi masalahmasalah dalam pembelajaran berhubungan dengan materi larutan elektrolit dan nonelektrolit (Hadinugrahaningsih, Rahmawati \& Ridwan, 2017).

$P j B L$ merupakan model pembelajaran gunanya untuk menuntut peserta didik menghasilkan suatu produk nyata, hal ini sangat berkaitan sekali dengan aspek pengetahuan berpikir kreatif. Menurut Gunawan \& Palupi (2016) yaitu ranah mencipta (create). Inovasi yang dilakukan dalam model $P j B L$ adalah mengkolaborasikan dengan STEAM (Science, Technology, Engineering, Art, Mathematics) dalam pembelajaran kimia. Penerapan model PjBL berbasis STEAM dapat mendorong kreativitas peserta didik dan memahami setiap komponen STEAM dalam studi kimia (Diawati, Liliasari, Setiabudi \& Buchari, 2017).

\section{METODE PENELITIAN}

Jenis Penelitian yang di terapkan adalah PTK model John Elliot dimulai dari tahapan rencana, tindakan, mengamati, dan refleksi terdiri dari dua siklus, setiap siklusnya terdiri dari 2 pertemuan transfer pengetahuan dan satu kali pertemuan untuk tes berpikir kreatif dan hasil belajar pengetahuan. Objek yang diteliti kelas X MIPA 5 di SMAN 7 Banjarmasin tahun ajaran 2018/2019. Seluruh peserta didik berjumlah 38 peserta didik. 
Penelitian ini menerapkan Teknik pengumpulan data berupa lembar observasi yang digunakan untuk mengukur data kualitatif seperti 1) aktivitas guru, 2) aktivitas peserta didik, 3) sikap, 4) keterampilan, 5) berpikir kreatif proyek mading 3 dimensi, untuk tes berpikir kreatif serta pengetahuan peserta didik, dianalisis secara kuantitatif yang dihitung melalui rumus berikut.

$$
N P=\frac{R}{S M} \times 100
$$

Hasil dari perhitungan data kualitatif dan kuantitatif akan dianalisis untuk mengetahui meningkat atau tidaknya pembelajaran yang diterapkan.

\section{HASIL PENELITIAN DAN PEMBAHASAN}

Hasil observasi analisis dan perhitungan yang telah dilakukan, yaitu a) analisis tindakan, b) aktivitas guru, c) aktivitas peserta didik, d) sikap, e) keterampilan f) proyek mading 3 dimensi berbasis $S T E A M \mathrm{~g}$ ) tes berpikir kreatif $\mathrm{h}$ ) tes hasil belajar pengetahuan dengan menggunakan model PjBL Berbasis STEAM. Hasil data dapat dilihat sebagai berikut:

\section{Analisis Tindakan}

Pada pembelajaran menggunakan model PjBL berbasis STEAM dengan sintak pembelajaran yaitu menentukan pertanyaan mendasar, merancang Proyek, menyusun jadwal proyek, memonitor proyek, menguji proyek dan evaluasi ditemukan tindakan yang tepat pada siklus 2 yaitu 1) bertukar pikiran dengan kelompok, 2) memberikan opsi/pilihan jawaban,3) memberikan arahan dalam pembuatan proyek mading 3 dimensi berbasis STEAM, 4) membimbing dalam mengajukan pertanyaan, sehingga keberhasilan tindakan disertai dengan peningkatan berpikir kreatif dan hasil belajar. sehingga keberhasilan tindakan disertai dengan peningkatan berpikir kreatif dan hasil belajar.

\section{Aktivitas Guru}

Aktivitas guru dengan menggunakan Model PJBL berbasis STEAM dengan 2 siklus. Penjelasan di setiap siklus sebagai berikut:

\section{Siklus I}

Pada Pertemuan pertama guru masih kurang tegas dalam mengkondisikan kelas sehingga terdapat kelas yang ribut. Pada Pertemuan kedua guru memperbaiki pembelajaran di kelas supaya efektif. Guru juga membimbing peserta didik dalam pembuatan proyek mading 3 dimensi dan menegur peserta didik yang rebut.

\section{Siklus II}

Pada pertemuan pertama guru merefleksi kekurangan pada siklus I dengan menggunakan tindakan-tindakan lain yaitu memberikan opsi untuk memudahkan peserta didik menemukan jawaban yang tepat serta membuat peserta didik lebih memahami setiap tahapan dalam model PjBL berbasis STEAM dan memberikan bimbingan kepada peserta didik di setiap sintak agar berpikir kreatif dan hasil belajar meningkat.

Pada pertemuan kedua terlihat adanya kemajuan dalam melaksanakan kegiatan pembelajaran. Hasil observasi aktivitas guru dapat dilihat pada grafik berikut: 


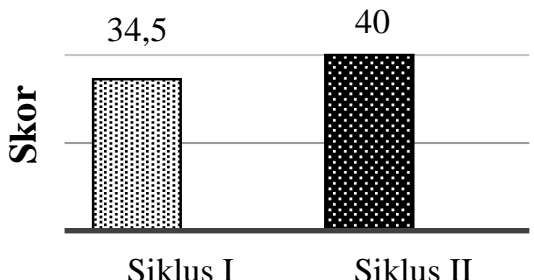

Gambar 1. Hasil observasi aktivitas guru siklus I dan siklus II

Aktivitas guru mengalami peningkatan. Hal ini dikarenakan guru melakukan perbaikan pembelajaran di kelas seperti perencanaan pembelajaran, pengefisienan waktu dan mengkondidikan kelas yang ribut. Hal ini sejalan dengan penelitian Azreen \& Mohamed (2014) mengungkapkan bahwa aktivitas kritis peserta didik penting terutama saat dihadapkan pada suatu permasalahan yang klasikal, sehingga guru diharuskan lebih tegas dalam bersikap.

\section{Aktivitas Peserta didik}

Aktivitas peserta didik menggunakan model PjBL berbasis STEAM dengan 2 siklus. Penjelasan di setiap siklus sebagai berikut:

\section{Siklus I}

Pada saat melakukan pembelajaran dengan model PjBL peserta didik belum dapat menghubungkan pengetahuan sebelumnya dengan pengetahuan yang baru dalam membuat proyek mading 3 dimensi, peserta didik masih perlu bimbingan guru dalam hal pembuatan proyek dan membangun pengetahuan yang sudah diperolehnya, sedangkan untuk memaksimalkan pembelajaran diperlukan kerjasama antar peserta didik.

\section{Siklus II}

Peserta didik dapat menerapkan pembelajaran menggunakan model $P j B L$ berbasis STEAM. Hal ini Sejalan dengan prinsip belajar bagi peserta didik menurut Riyanto (2012) yang menyatakan bahwa peserta didik sebagai ujung tombak keberhasilan pembelajaran yang dituntut untuk selalu aktif memproses dan mengolah perlahan belajarnya secara fisik, intelektual, dan emosional. Hasil observasi aktivitas peserta didik dilihat pada grafik berikut:

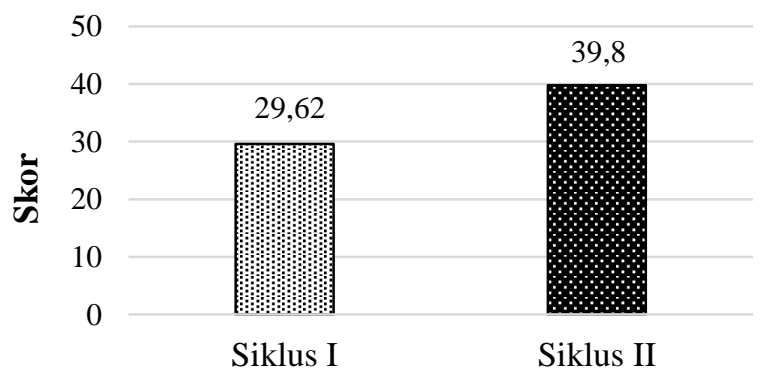

Gambar 2. Hasil observasi aktivitas peserta didik siklus I dan siklus II 
berdasarkan hasil penilaian observer menyatakan bahwa, pembelajaran mengalami peningkatan pada setiap siklus sehingga didapat rata-rata skor pada siklus I sebesar 29,62 dikategorikan cukup aktif, pada siklus II sebesar 39,80 dikategorikan aktif.

\section{Sikap Peserta didik}

Hasil observasi sikap peserta didik menggunakan model PjBL berbasis STEAM di setiap siklus. Penjelasan di setap siklus sebagai berikut:

\section{Siklus I}

Aspek sikap peserta didik dikatagorikan masih cukup karena kerjasama, rasa ingin tahu, dan tanggung jawab belum optimal dan harus diperbaiki setiap pertemuannya. Kekurangan tersebut dilihat setiap tahapan pemberian transfer ilmu.

\section{Siklus II}

Guru memotivasi peserta didik yang pasif dan membimbing setiap tahapan pembelajaran terutama dalam pembuatan proyek mading 3 dimensi sehingga aspek sikap peserta didik mengalami peningkatan. Selain itu pada setiap pertemuan guru selalu memperbaiki tindakan dengan baik, jika peserta didik dapat membuat proyek mading 3 dimensi dengan baik dan saling bekerja sama, maka akan meningkatkan sikap peserta didik dengan baik pula. Hasil rata-rata skor pembelajaran dapat dilihat di grafik berikut:

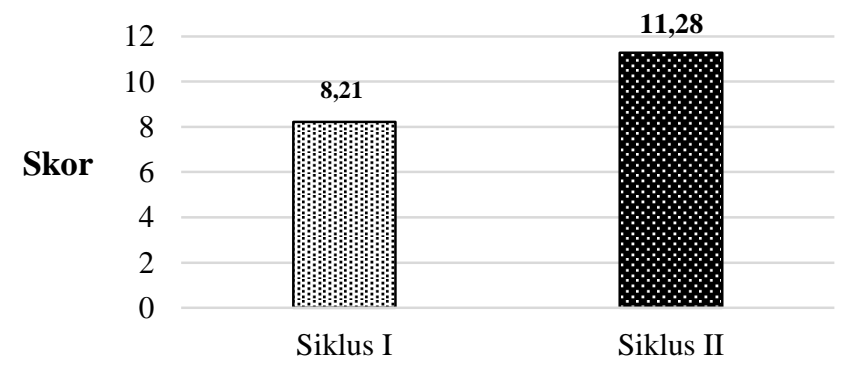

Gambar 3. Hasil perbandingan Sikap peserta didik siklus I dan Siklus II

Hasil perhitungan penilaian observer menyatakan bahwa, pada proses belajar mengajar di siklus ini mengalami peningkatan yaitu pada siklus I sebesar 8,21 dikategorikan cukup baik, siklus II sebesar 11,28 dikategorikan baik.

\section{Keterampilan Peserta didik}

Aspek yang dinilai pada saat melakukan praktikum yaitu di setiap siklus hanya 1 kali pertemuan. menggunakan lembar observasi yang disertai rubrik penilaian yang diisi oleh observer. Penjelasan setiap siklus sebagai berikut:

\section{Siklus I}

Tahap ini cukup terampil dalam menggunakan elektroda, pada saat menggunakan elektroda sudah membersihkan elektroda dengan tisu walaupun masih ada yang tidak membersihkan. Guru sudah mendorong kemauan dalam hal menerima pembelajaran yang diberikan 


\section{Siklus II}

Siklus II mengalami peningkatan dan secara keseluruhan mendapat kategori terampil. Peserta didik sudah dapat menggunakan elektroda dengan terampil, merangka alat uji elektrolit dan nonelektrolit dengan terampil dan membagikan larutan kedalam gelas kimia dengan terampil. Hal ini karena guru telah memperbaiki tindakan yang dilakukan, tindakan yang dilakukan guru adalah dengan menjelaskan cara merangkai alat dengan melakukan demonstrasi di supaya semua dapat melakukan dengan terampil. Hasil rata-rata skor pembelajaran dapat dilihat di grafik berikut:

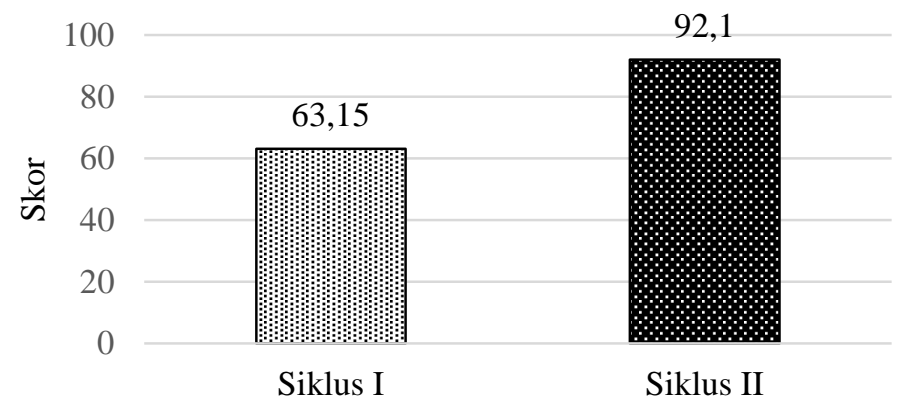

Gambar 4 Hasil perbandingan keterampilan peserta didik siklus I dan Siklus II

Berdasarkan perhitungan penilaian observer menyatakan bahwa, keterampilan pada proses transfer pengetahuan menggunakan model PjBL berbasis STEAM diperoleh rata-rata siklus I sebesar 8,47 kriteria cukup terampil, sedangkan pada siklus II sebesar 10,76 kriteria terampil.

\section{Berpikir kreatif proyek STEAM Peserta didik}

Pembelajaran dengan menggunakan proyek akan lebih mudah membuat peserta didik aktif dalam meningkatkan kreatifitasnya Handayani (2014). Penjelasan setiap siklus sebagai berikut:

\section{Siklus I}

Pada proyek mading 3 dimensi yang dibuat di siklus I, peserta didik masih belum dapat mengintegrasikan STEAM yang terlihat dari pembuatan rangkaian alat dari energi buah-buahan yang belum selesai. Hal ini disebabkan transfer ilmu yang terbatas diberikan, lemahnya komunikasi dan kolaborasi untuk menyelesaikan proyek, peserta didik juga kurang memperhatikan penjelasan guru.

Berikut ini salah satu hasil mading 3 dimensi peserta didik kelompok 2 pada siklus I sebagai berikut :

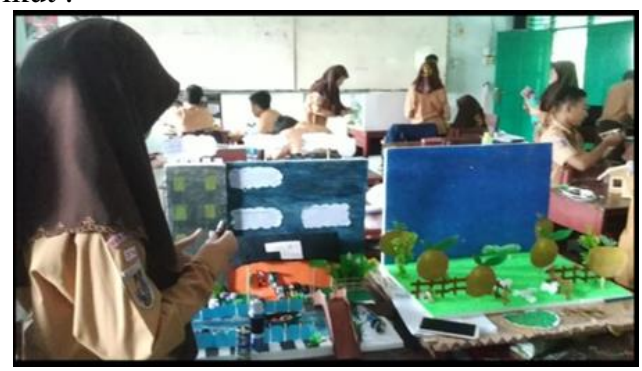

Gambar 5. Mading 3 dimensi berbasis STEAM pada siklus 1 kelompok 2 


\section{Siklus II}

Pada siklus II berpikir kreatif proyek STEAM peserta didik sudah kreatif. Terlihat pada hasil mading 3 dimensi kelompok 2 sebagai berikut :

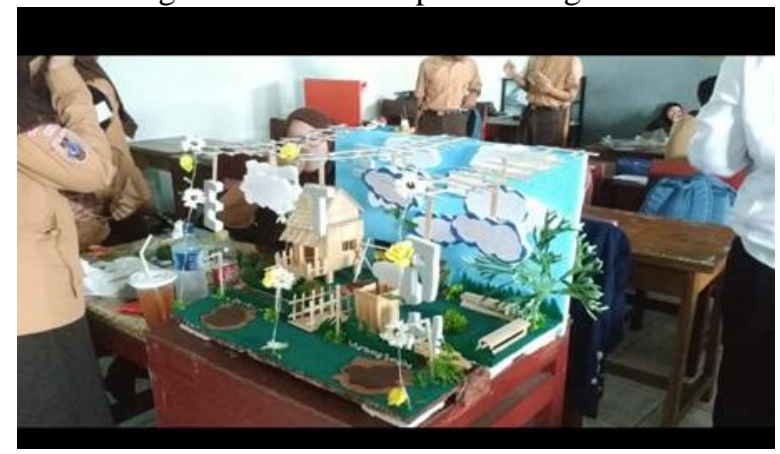

Gambar 6. Mading 3 dimensi berbasis STEAM pada siklus II

Semua kelompok sudah menyelesaikan proyek mading 3 dimensi berbasis STEAM yang di minta oleh guru. Pada proyek mading 3 dimensi yang dibuat oleh peserta didik di siklus II, peserta didik sudah dapat mengintegrasikan STEAM dalam pembuatan rangkaian alat dari energi buah-buahan, peserta didik sudah dapat melilit kabel ke elektroda, dan sudah bisa dalam menentukan katoda dan anoda. Hal ini disebabkan sudah membimbingnya guru dalam setiap transfer pengetahuan. Hasil rata-rata skor pembelajaran dapat dilihat di grafik berikut:

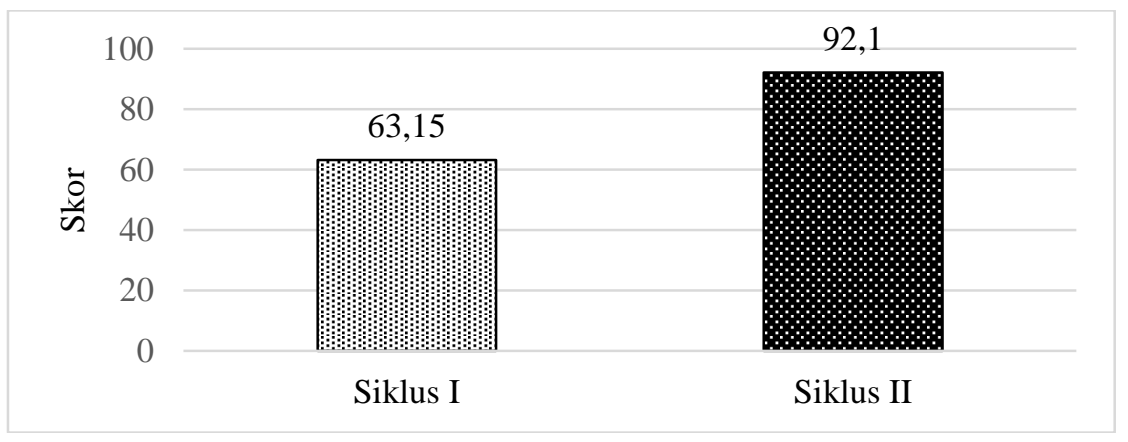

Gambar 7. Peningkatan rata-rata berpikir kreatif proyek STEAM peserta didik siklus I dan II

Berdasarkan perhitungan penilaian observer menyatakan bahwa pengolahan proyek STEAM pada proses belajar mengajar menggunakan model pembelajaran $P j B L$ didapat rata-rata siklus I sebesar 23,63 digolongkan cukup kreatif, siklus II sebesar 35,00 digolongkan kreatif. Hal ini disebabkan karena adanya perbaikan dalam cara mengajar guru dan tindakan yang diberikan sehingga mempengaruhi peserta didik dalam pembuatan proyek STEAM pada siklus II menjadi lebih kreatif. Penelitian Annisa, Effendy \& Damris (2018) Penerapan model PjBL dapat meningkatkan prestasi belajar dan kreativitas, hal ini ditunjukkan semakin banyak siswa yang bertanya, mengungkapkan pendapat dan menjawab pertanyaan oleh guru 


\section{Hasil Tes Berpikir Kreatif Peserta didik}

Pengukuran hasil tes berpikir kreatif. berpikir kreatif dari butir soal uraian (essay) sebanyak 4 soal dengan masing-masing indikator. Indikator berpikir kreatif yaitu Fluence, Flexibility, Originality, Elaboration. Analisis terhadap berpikir kreatif dijelaskan setiap siklus sebagai berikut :

\section{Siklus I}

Hasil Penelitian Siklus I dapat dilihat pada Tabel berikut:

Tabel 1. Hasil tes berpikir kreatif siklus I

\begin{tabular}{ccc}
\hline No. & Indikator & Nilai \\
\hline 1 & Fluence & 2,13 \\
2 & Flexibility & 2,68 \\
3 & Originility & 1,89 \\
4 & Elaboration & 2,66 \\
\hline & Rata-rata siklus I & 9,36 \\
& Kategori & Cukup Kreatif \\
\hline
\end{tabular}

\section{Indikator Fluency}

Nilai rata-rata 2,13 masih sedikit kurang. Terlihat pada soal yang dijawab peserta didik pada gambar sebagai berikut :

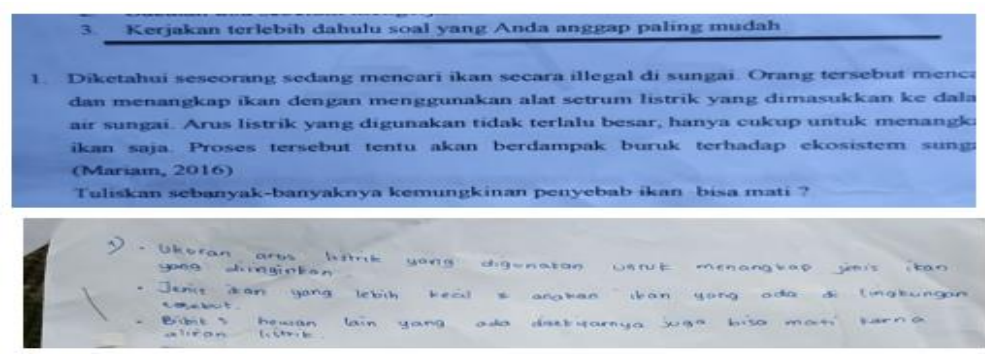

Gambar 8. Jawaban pada Indikator Fluency Siklus I

Menunjukan bahwa masih belum dapat memberikan ide-ide yang tepat untuk memecahkan soal, terlihat pada jawaban yang kurang logis yaitu peserta didik belum dapat menyebutkan jawaban sebanyak-banyaknya kemungkian penyebab ikan bisa mati. Hal ini karena peserta didik belum paham sepenuhnya cara menghasilkan banyak ide, sehingga guru harus membimbing pengetahuan peserta didik dalam materi elektrolit dan nonelektrolit yang lebih mengaitkan materi ke kehidupan seharihari.

\section{Indikator Flexibility}

Nilai rata-rata 2,68 . Terlihat dari soal yang dijawab oleh peserta didik sebagai berikut.

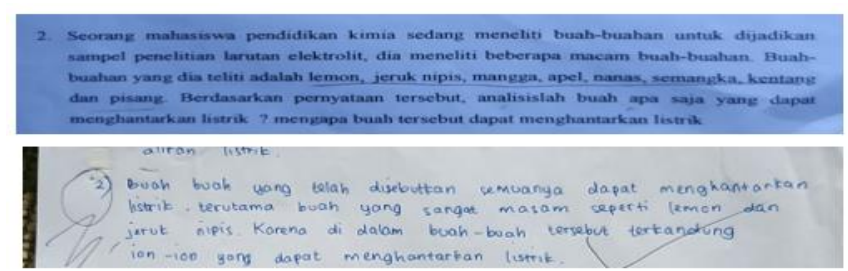

Gambar 9. Jawaban pada Indikator Flexibility Siklus I 
Menunjukan bahwa jawaban sudah tepat tetapi belum dapat memberikan jawaban dengan lengkap dan memberikan alasan dengan jelas tentang menganalisis mengapa buah-buahan dapat menghantarkan listrik. Hal ini karena peserta didik belum paham sepenuhnya cara menerapkan ide dalam menyelesaikan masalah.

\section{Indikator Originality}

Nilai rata-rata 1,89 masih dalam kategori kurang. Terlihat pada gambar sebagai berikut:

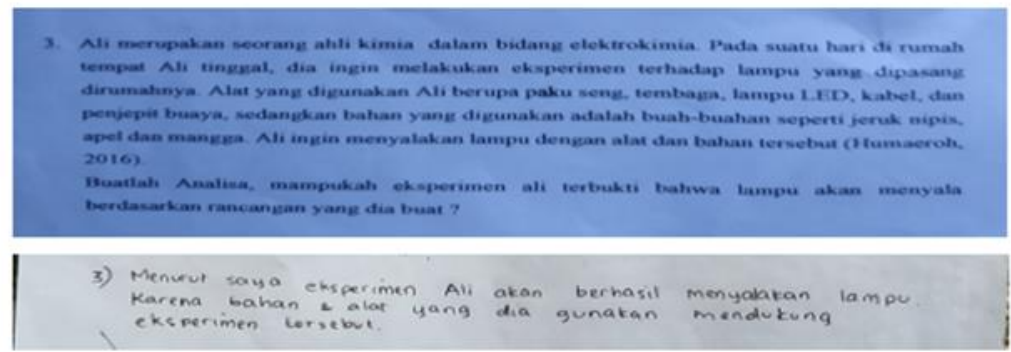

Gambar 10. Jawaban pada Indikator Originality Siklus I

Jawaban tersebut belum dapat menghasilkan ide baru. Terlihat pada jawaban yang masih sama tentang menganalisis rancangan eksperimen terbaru larutan elektrolit dan nonelektrolit. Hal ini karena belum memahami cara menemukan ide baru dalam menyelesaikan masalah. Indikator originality ini sangat sulit karena perlu pemahaman yang lebih dalam.

\section{Indikator Elaboration}

Nilai rata-rata 2,66. Terlihat pada gambar sebagai berikut :

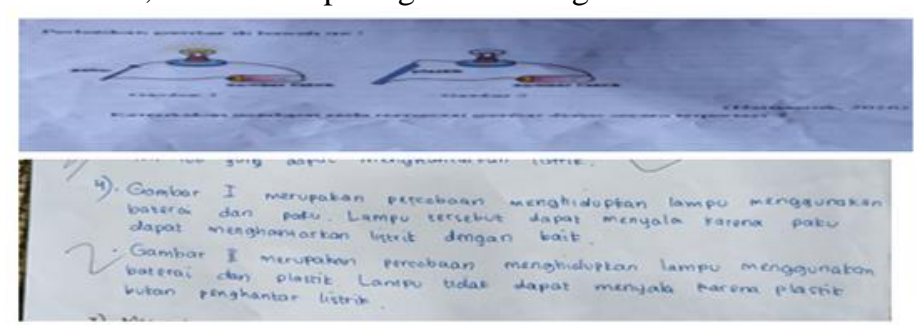

Gambar 11. Jawaban pada indikator Elaboration Siklus I

Jawaban sudah benar tetapi belum dapat merincikan jawaban dengan lengkap seperti pada soal diatas yaitu diminta untuk merincikan gambar tersebut. Hal ini karena belum mengerti sepenuhnya cara menerapkan ide dalam menyelesaikan masalah.

\section{Siklus II}

Hasil Penelitian Siklus I dapat dilihat pada Tabel berikut:

Tabel 2. Hasil tes berpikir kreatif siklus II

\begin{tabular}{ccc}
\hline No. & Indikator & Nilai \\
\hline 1 & Fluence & 3,29 \\
2 & Flexibility & 2,97 \\
3 & Originility & 2,26 \\
4 & Elaboration & 3,03 \\
\hline & Rata-rata siklus I & 11,55 \\
& Kategori & Kreatif \\
\hline
\end{tabular}


Pada siklus II mengambil sampel jawaban salah satu peserta didik kelompok 2. Pada indikator Fluency rata-rata skornya 2,39. Sependapat dengan penelitian Indriana, Arsyad \& Mulbar (2015) menyatakan bahwa peningkatan berpikir kreatif pada indikator fluency terlihat dari hasil tes.

Pada indikator flexibility rata-rata skor sebesar 2,97 dan mengalami peningkatan. Hal ini karena guru sudah melatih dalam menjawab soal pada saat pembelajaran berlangsung. Sejalan sama penelitian Wahyu, Rusmansyah \& Sholahuddin, (2017) terlihat banyak peserta didk yang dapat menyelsaikan masalah dengan cara berpikir luwes dan berani memberi argument di setiap pembelajaran.

Pada indikator Originality rata-rata skor sebesar 2,26 mengalami peningkatan hasil belajar. Nehe (2017) berpendapat kemampuan berpikir kreatif merupakan kemampuan berpikir tingkat matematis termasuk dalam keahlian, elaborasi, kelanturan dan keabsahan.

Pada Indikator Elaboration rata-rata skor sebesar 3,03 mengalami peningkatan, karena peserta didik sudah terbiasa dalam mengerjakan soal seperti ini dan pada indikator ini meningkatnya sangat drastis.

Terjadi peningkatan karena guru selalu membimbing dalam setiap pembelajaran dan selalu mengaitkan pembelajaran dengan fenomena-fenomena alam sekitar, karena materi larutan elektrolit dan nonelektrolit ini sangat berkaitan erat dengan alam. Guru juga memberikan latihan soal supaya membiasakan dalam berlatih, mengambil tindakan dan mengambil keputusan dengan baik. Hasil rata-rata skor dapat dilihat di grafik berikut:

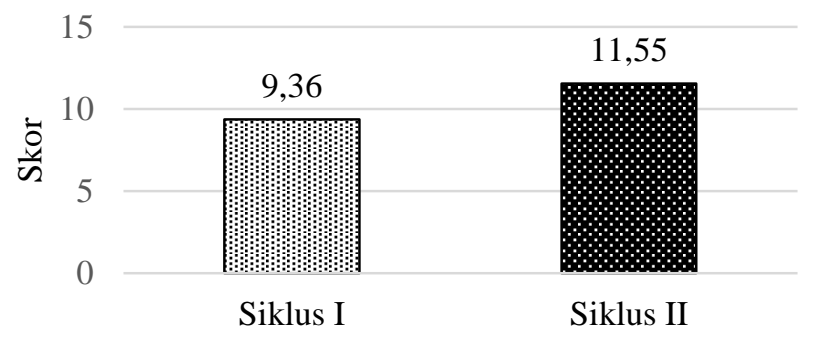

Gambar 12. Peningkatan Rata-rata Tes Berpikir kreatif peserta didik

\section{Hasil Belajar pengetahuan peserta didik}

Meningkatnya aspek setiap pembelajaran yang dilakukan berdampak pula pada meningkatnya hasil belajar pengetahuan peserta didik. Terlihat penjelasan setiap siklus sebagai berikut:

\section{Siklus I}

Berikut ini Tabel ketuntasan hasil belajar siklus I sebagai berikut:

Tabel 3. Hasil tes berpikir kreatif siklus II

\begin{tabular}{ccc}
\hline Nilai & Jumlah Peserta Didik & Kategori \\
\hline $91-100$ & 2 & Sangat tinggi \\
$83-90$ & 6 & Baik \\
$75-82$ & 16 & Sedang \\
$<75$ & 14 & Rendah \\
\hline
\end{tabular}

Data tes hasil belajar pengetahuan pada siklus 1 dapat dilihat pada Tabel sebagai berikut: 
Tabel 4. Hasil belajar siklus I

\begin{tabular}{clcc}
\hline No. & \multicolumn{1}{c}{ Indikator } & Nilai & Kategori \\
\hline 1 & $\begin{array}{l}\text { Menjelaskan dan } \\
\text { menentukan gejala-gejala } \\
\text { hantaran arus listrik }\end{array}$ & 98,94 & Sangat tinggi \\
& $\begin{array}{l}\text { Mengelompokkan } \\
\text { larutan elektrolit dan non } \\
\text { elektrolit berdasarkan } \\
\text { daya hantar listriknya }\end{array}$ & 89,07 & Baik \\
& $\begin{array}{l}\text { Menganalisis penyebab } \\
\text { sifat dan jenis } \\
\text { kemampuan larutan } \\
\text { elektrolit berdasarkan } \\
\text { daya hantarnya }\end{array}$ & 58,58 & Rendah \\
Rata-rata siklus I & & Sedang \\
\hline
\end{tabular}

Hasil pengetahuan siklus I tersebut menunjukan bahwa peserta didik sudah mampu menjawab soal namun kurang teliti dan kurang nya pemahaman peserta didik dalam memberikan alasan yang membuat banyaknya pengurangan skor dalam menjawab soal. Cara yang dilakukan guru dengan memberi soal-soal yang menyangkut materi larutan elektrolit dan nonelektrolit untuk memperbaiki hal tersebut. Putra, Irwan \& Dodi (2012) yang menyatakan keterlibatan dalam komunikasi dua arah perihal transfer pengetahuan dan didukung dengan suasana belajar-mengajar yang baik akan memperbaiki pencapaian pembelajaran yang baik pula.

\section{Siklus II}

Berikut ini Tabel ketuntasan hasil belajar siklus I sebagai berikut:

Tabel 5. Ketuntasan hasil belajar siklus II

\begin{tabular}{ccc}
\hline Nilai & Jumlah Peserta Didik & Kategori \\
\hline $91-100$ & 6 & Sangat tinggi \\
$83-90$ & 9 & Baik \\
$75-82$ & 20 & Sedang \\
$<75$ & 3 & Rendah \\
\hline
\end{tabular}

Data tes hasil belajar pengetahuan pada siklus II dapat dilihat pada Tabel berikut:

Tabel 6. Hasil belajar siklus II

\begin{tabular}{clcc}
\hline No. & \multicolumn{1}{c}{ Indikator } & Nilai & Kategori \\
\hline 1 & $\begin{array}{l}\text { Menganalisis penyebab } \\
\text { kemampuan larutan } \\
\text { elektrolit menghantar } \\
\text { listrik }\end{array}$ & 94,40 & Sangat tinggi \\
2 & $\begin{array}{l}\text { Menganalisis larutan } \\
\text { elektrolit dapat berupa } \\
\text { senyawa ion dan } \\
\text { senyawa kovalen polar }\end{array}$ & 82,63 & Sedang \\
\hline & & Baik \\
\hline
\end{tabular}


Tingkat ketuntasan memperoleh kenaikan yaitu 35 peserta didik dari 38 peserta didik yang tuntas. Hal ini sebab guru melakukan perbaikan dalam pembelajaran sehingga lebih memahami pada saat dilakukan tes hasil belajar. Pendapat tersebut disepakati oleh penelitiandilakukan Fitria (2017) menunjukkan pembelajaran dengan model pembelajaran project based learning dapat meninggikan hasil belajar pada materi koloid dengan menciptakan produk yang sangat menunjang pembelajaran. Berikut ini grafik penilaian hasil belajar sebagai berikut:

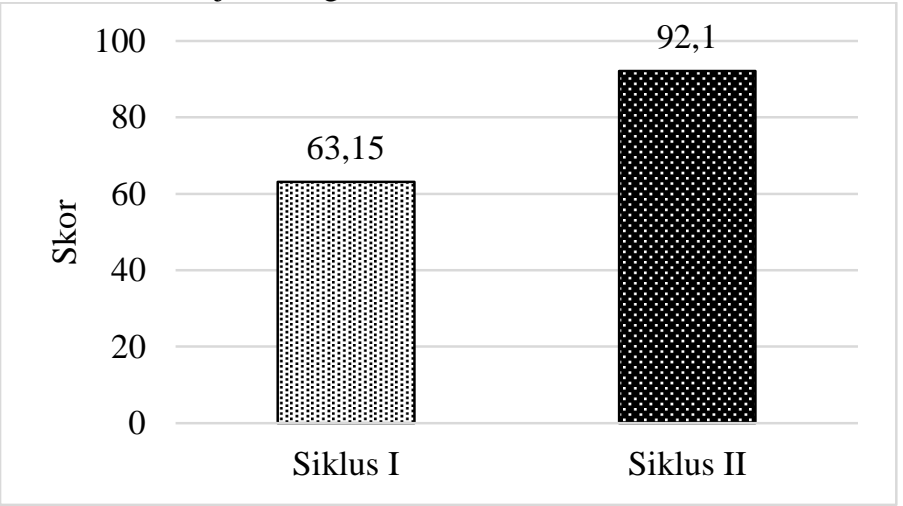

Gambar 13. Peningkatan hasil belajar siklus I dan II

\section{SIMPULAN}

Berdasarkan data hasil penelitian yang telah dilakukan, dapat ditarik kesimpulan sebagai berikut.

a) Setelah ditemukan tindakan yang tepat pada setiap sintak menggunakan model $P j B L$ berbasis STEAM meningkatkan berpikir kreatif dan hasil belajar peserta didik.

b) Penggunaan Model PjBL berbasis STEAM meningkatkan berpikir kreatif peserta didik. Pada siklus I sebesar 9,36 kategori cukup kreatif dan pada siklus II sebesar 11,55 kategori kreatif.

c) Penggunaan Model PjBL berbasis STEAM dapat meningkatkan hasil tes belajar pengetahuan peserta didik pada siklus I sebesar 63,15 kategori rendah dan pada siklus II sebesar 92,10 kategori sangat tinggi.

\section{DAFTAR RUJUKAN}

Annisa, R., Effendy, M, H., \& Damris. (2018). Peningkatan Kemampuan Berpikir Kreatif Siswa dengan Menggunakan Model Project Based Learning Berbasis STEAM Pada Materi Asam dan Basa di SMAN 11 Kota Jambi. Journal of the Indonesia Society of Integrated Chemistry, 10(2), 14-22.

Azreen, R \& Mohamed, M. (2014). The Perception of Critical Thinking and Problem Solving Skill Among Malysian Undergraduate Students. Journal Social and Behaviorall Science, 1 (172), 725-732.

Diawati, C., Liliasari, Setiabudi, A., \& Buchari. (2017). Student' Construction Of Simple Steam Distillation Apparatus And Development Of Creative Thingking Skills : A Project-Based Learning. Mathematics, Science, and Computer Science Education.

Fitria, A. (2017). Pengaruh Model Pembelajaran Project Based Learning Terhadap Hasil Belajar Siswa Pada Materi Koloid di MAN Indrapuri Aceh Besar. Universitas Islam Negeri Ar-raniry. 
Gunawan, I., \& Palupi, A, R. (2016). Taksonomi Bloom - Revisi Ranah Kognitif : Kerangka Landasan Untuk Pembelajaran, Pengajaran, dan Penilaian. Premiere Educandum: Jurnal Pendidikan Dasar dan Pembelajaran, 16-40

Hadinugrahaningsih, T., Rahmawati, Y., \& Ridwan, A.(2017). Developing 21st Century Skills in Chemistry Classrooms: Opportunities and Challenges of STEAM Integration. Journal chemistry Education Study Program, 1868 (1).

Handayani, D, T., Karyasa, W., \& Suardana, N. (2015). Komparasi Peningkatan Pemahaman Konsep dan Sikap Ilmiah Siswa SMA yang Dibelajarkan dengan Model Pembelajaran Problem Based Learning dan Project Based Learning. Jurnal Program Pascasarjana, (5).

Indriana, V., Arsyad, N., \& Mulbar, U. (2015). Penerapan Pendekatan Pembelajaran POE Untuk Meningkatkan Kemampuan Berpikir Kreatif Siswa Kelas XI IPA 1 SMAN 22 Makassar, 3(1).

Nehe, M., Surya, E., \& Syahputra, E. (2017). Creative Thinking Ability To Solving Equation an Non-Equation of Linear Single Variable In VII Grade Junior High School. Journal of advance research and Innovative Ideas In Education, 3(1)

Putra, T.T., Irwan., \& Dodi, V. (2012). Meningkatkan Kemampuan BerpikirKreatif Siswa dengan Pembelajaran Berbasis Masalah. Jurnal Pendidikan Matematika, 1(1), 49-53.

Riyanto, Y. (2012). Paradigma Baru Pembelajaran Sebagai Referensi Bagi Pendidik Dalam Implementasi Pembelajaran yang Efektif dan Berkualitas. Jakarta: Kencana.

Saptorini, W. A. (2014). Green Chemistry Dalam Desain Pembelajaran Project Based Learning Berbasis Karakter Di Madrasah Aliyah Se Kabupaten Demak. Jurusan Kimia FMIPA, 12(1).

Wahyu, Rusmansyah, \& Sholahuddin, A. (2017). Meningkatkan Kemampuan Berpikir Kreatif dan Self Efficacy siswa Menggunakan Model Creative Problem Solving Pada Materi Sistem Koloid, Jurnal Vidya karya. 32(1) 